\title{
Neurosurgical practice in the current regulatory environment
}

\author{
JoHn A. KusSKe, M.D. \\ Department of Neurological Surgery, University of California Irvine Medical Center, Orange, \\ California
}

\begin{abstract}
The practice of neurosurgery has been complicated over the last 25 years by the enactment of a series of statutes that have significantly altered the time-honored means by which neurosurgeons manage their work. These laws deal with issues that neurosurgeons have not customarily had to consider. The author outlines some of the socioeconomic and political matters that led to the passage of these statutes. An assortment of the laws is then surveyed, to foster an appreciation for the variety and depth of health care law that affects neurosurgeons' practice and the delivery of care to their patients. Statutes discussed include the fraud and abuse laws, self-referral laws, the Emergency Medical Treatment and Labor Act, Health Insurance Portability and Accountability Act, and Employee Retirement Income Security Act.
\end{abstract}

\section{KEY WoRDS • neurosurgery • fraud • law, antitrust • Emergency Medical Treatment and Labor Act • Employee Retirement Income Security Act • Health Insurance Portability and Accountability Act}

\begin{abstract}
It will be of little avail to the people that the laws are made by men of their own choice if the laws are so voluminous that they cannot be read or so incoherent they cannot be understood. Alexander Hamilton, The Federalist Papers

There was a time when the US health care industry was not wholly burdened by law and lawyers. There was a time when it was irrelevant for most neurosurgeons to be familiar with a wide body of law ranging from antitrust law to antikickback statutes, and from rules on self-referral to statutes regulating ER coverage. In the late 1960s the list of significant legal issues in health care was short. The leading topics were focused on a few fields of the law, primarily medical malpractice, the area of informed consent, licensure, abortion, prescription drug development, human experimentation, and the tort liability of hospitals. Although the Medicare and Medicaid programs were in place, they presented no major legal problems because they were still operating under widely-accepted principles borrowed from private, nonprofit health insurance. The
\end{abstract}

Abbreviations used in this paper: DHS = designated health service; $\mathrm{ER}=$ emergency room; ERISA = Employee Retirement Income Security Act; EMTALA = Emergency Medical Treatment and Active Labor Act; FCA = False Claims Act; HHS = Health and Human Services; HIPAA = Health Insurance Portability and Accountability Act; $\mathrm{HMO}=$ health maintenance organization; $\mathrm{MCO}=$ managed care organization; OIG = Office of the Inspector General; US $=$ United States . latter issue itself had not yet become controversial or raised prominent legal issues. Workers in the field did not foresee an explosion of new laws and legal attacks on time-honored traditions in the practice of health care. Health care was viewed as a public service, not as a business requiring a complex legal scheme to ensure that it functioned responsibly. As Havighurst ${ }^{16}$ has asserted, the law largely ignored the health care industry and nearly everyone thought such autonomy would always continue.

What has occurred since the 1960s to create the present legal morass? Are there explanations for the proliferation of legal rules and associated legal risks that have lately overwhelmed health care providers, payers, and others? Where did all these laws come from? The first portion of this discussion deals with events in the last 50 years that have led to the present situation. In the second portion of this paper, various statutes will be reviewed and their relationship to the current practice of neurosurgery in the US will be illustrated.

\section{SIGNIFICANT EVENTS IN AMERICAN HEALTH CARE}

\section{The Law and Unintended Consequences}

The US legal system has been a major factor in creating conditions that determined how health care would evolve over the past half century. In relation to several seminal events, significant implied legal changes associated with 


\section{J. A. Kusske}

these events were not recognized by the public, decision makers, and those inside the industry. ${ }^{16}$ Each of these events set the course for powerful political and economic forces that forever changed health care. Health care-related lawmaking has been driven by chance to a particularly surprising extent. For a more complete discussion of this issue, the reader is referred to Havighurst's excellent review of the topic. ${ }^{16}$ The evolution of the health care industry has been influenced by conditions that the legal system created with little awareness of what it was doing.

\section{Employer-Based Health Coverage}

The first event, which involved the subsidizing of employer-based health coverage, occurred during World War II. At that time employers were restricted from raising the take-home pay of their workers. Instead they offered bountiful health benefits to their employees because they were not costly. After the war, employers and workers lobbied successfully to have these benefits made tax free. The idea of subsidizing the purchase of health coverage seemed at the time to be a good, progressive idea. This modest concession, however, laid the groundwork for the present system of employer-based health insurance. The tax-free status of employer-paid health premiums has induced most consumers to pay as much of their health bills as possible through an employer-sponsored health plan, rather than from their own pockets. ${ }^{16}$

Subsequently, similar public coverage was extended to senior citizens ( $\geq 65$ years of age), the disabled, and certain poor individuals. The unrestricted "moral hazard" inherent in these arrangements soon gave rise to unprecedented cost escalation because cost/benefit ratios were almost totally neglected in physicians' clinical judgments. Similarly, decision making regarding capital spending and technological development was not grounded in objective analysis. The culprit most often blamed for the poor performance of the health care services market is the demand-liberating effect of health insurance- the effect that economists call moral hazard. This term is used by economists in reference to the behavioral changes that occur when individuals are put in a position to spend or risk the funds of others. ${ }^{16}$

Employment-based health coverage in which benefits are highly visible and costs are not has led to a pervasive sense of all-encompassing entitlement, which continues to distort public discussions about health care. The backlash against managed care grows out of working Americans' ability to see only the possible drawbacks of their coverage and not the savings that managed care has added to their paychecks. Thus, the tax policy adopted naively in the postwar period still affects the political, institutional, and legal climate in which health care is financed and provided. ${ }^{16}$ Attempts to cap the tax subsidy at appropriate levels have not fared well over the years. Politicians easily persuade voters to oppose the "taxing" of health care benefits. This is an off-budget public expenditure that amounted to $\$ 125$ billion in 1998, and significant amounts of society's resources are misallocated without individuals being aware of the loss. ${ }^{35}$ None of the stakeholders has an interest in calling attention to the fact that the US health care-related spending exceeds that of any other nation by several percentage points of gross domestic product. ${ }^{2}$ Examination of this prodigious spending reveals the magni- tude of the problem we created for ourselves when government elected to use the tax code to encourage employed workers to buy health coverage. ${ }^{18}$

\section{The Medicare and Medicaid Programs}

The new infusion of money through Medicare and Medicaid programs was a well-recognized watershed in health policy. Initally, many physicians were opposed to Medicare, believing that federal participation would lower their professional stature. Congress could not predict how the introduction of so much money into the health care industry, paired with the moral hazard that occurs with any form of third-party payment, would alter forever not only the economics but also the culture of health care. Perhaps Medicare's most significant effect was to make the health care sector an arena for profit-seeking activity more than any time in the past. ${ }^{16}$ For the young neurosurgeon, it is difficult to recall that the program, for the first time, made it possible for hospitals and physicians to be paid well for care they had previously provided for less. There was also a huge increase in the demand for even the costliest of services. Entrepreneurs realized new options in health care, and physicians saw opportunities to become entrepreneurs themselves. As Havighurst ${ }^{16}$ has pointed out, with so much money on the table, the law and lawyers could not be far behind. This was not so much because they were tempted by the money but because their services would be needed, as entrepreneurs rushed in and as the legal system was called upon to manage the inevitable disputes.

The manner in which the programs were designed exacerbated the potential for legal problems. Medicare was designed to resemble the Blue Cross Blue Shield plans that enabled consumers to purchase financial protection without impeding providers' freedom or introducing price competition. The inflationary pressure of such a program was clear because it contained few safeguards for battling moral hazard. The rising costs of the public programs eventually led to regulation-like reforms, with which we are dealing today. The Department of HHS estimates that Medicare fraud, abuse, and payment errors cost taxpayers $\$ 11.9$ billion annually-more than $\$ 32$ million per day. ${ }^{22}$ Others, however, caution that this figure may be high because inadvertent mistakes — such as improperly coding claims-are considered fraud. ${ }^{3}$

\section{Weakness in the Medicare Program Design}

The federal campaign against perceived fraud and abuse reveals another weakness in the primary design of Medicare. As part of its original formulation, Medicare allowed beneficiaries "free choice of providers" and permitted any provider to participate unless the government could show cause why they should not. Thus, the government was deprived of the ability to protect itself against abuse related to inappropriate kickbacks and self-referrals. In time the problem surfaced, but Medicare eventually became extremely vulnerable to schemes designed by individuals to induce lucrative referrals of beneficiaries. ${ }^{16}$ The government was unable to ensure that abuses were not occurring and was alerted to the fact that profiteering was ongoing. Therefore, on at least seven occasions between 1972 and 1996, increasingly severe antifraud legis- 
lation was enacted. ${ }^{16}$ Because of these laws, the federal government now uses the threat of criminal prosecution and severe civil penalties against providers who-it perceives - have taken advantage of faults in Medicare's design and administration. These statutes will be described in more detail as they relate to neurosurgeons. Havighurst ${ }^{16}$ is very clear on this: "Although some providers are unduly opportunistic, much of the conduct subject to penalty under the anti-kickback and Stark legislation (aimed to curb referral abuses) appears fairly well sanctioned and manageable in the private sector. Nevertheless, government has found it convenient to characterize provider conduct that exploits the programs shortcomings as 'fraud and abuse' and to criminalize it." This tack was necessary to eschew the concept that all providers are entitled to provide Medicare services and to shift the onus for the program deficits away from its originators.

Neurosurgeons should keep in mind that Medicare is a pay-as-you-go system in which the government collects money from taxpayers and uses it to pay part of senior citizens' medical bills. It does so by contracting with 60 insurance companies to process claims for some 39 million Americans. ${ }^{27}$ In July 1999 the Government Accounting Office released a study in which it was revealed that contractors hired to root out Medicare fraud were themselves implicated in wrongdoing and had been forced to pay at least $\$ 235$ million in civil and criminal penalties since $1993 .{ }^{27}$

\section{Antitrust Law}

The application of antitrust law to physicians has also led to significant alterations in the health care sector since the mid-1970s. The 1975 Supreme Court decision in Goldfarb v. Virginia State Bar led to the creation of a new environment for physicians. ${ }^{46}$ The decision simply stated that the so-called learned professions are engaged in "trade or commerce" and are not entitled to an exemption from the Sherman Act. The original case involved collusive price fixing among attorneys, and this soon extended to the medical profession. ${ }^{17}$ Before this decision was rendered both government and the private sector had, for the most part, acceded in the medical profession's view of itself as a self-regulating body and accepted its control over major portions of the health care system. Competition in the health care industry was not a major consideration. Market forces were often overlooked. The policy that professionals could be entrusted to formulate the basic rules under which health care was provided was torn asunder. Competitors could no longer lawfully agree to restrain competition. Thus, one Supreme Court decision, with little or no public debate, changed the basic legal landscape governing professional services. Private innovations that were procompetitive became commonplace. The decision also made plausible market-oriented health care policy. ${ }^{17}$ This occurred because the medical profession could no longer exercise effective control over the physician's economic environment and thus it could not prevent the evolution of corporate middlemen. These corporate middlemen could act as purchasing agents for consumers by obtaining physician services competitively. Significant reform could occur in the private sector without direct government involvement. ${ }^{17}$
In 1981 the US Supreme Court ruled that physician associations created solely for the purpose of negotiating fees with insurers were engaged in illegal price fixing. Only if physicians pooled their assets by creating multispecialty clinics or prepaid independent practice associations were they judged to be engaged in efficiency-enhancing forms of organizational integration and were hence exempt from price-fixing charges. ${ }^{32}$ In the succeeding years, the federal antitrust agencies prosecuted physician organizations that attempted to ban advertising to consumers, to limit price competition through relative value scales, and to boycott reviews of questionable clinical practices. $^{32}$

Havighurst ${ }^{16}$ has argued that the Goldfarb decision was a singular event in the evolution of US health care policy. Much earlier, because of an antitrust case in which a Washington, D.C., HMO was vindicated, the possibility of creating health care-related alternative delivery systems and preserving price competition was kept alive. ${ }^{1}$ The practical importance of the antitrust initiatives was to hamstring the medical profession's resistance to prepaid group practice, managed care, and the spread of competition in health markets. The symbolic importance was to formalize a rejection of the profession's worldview. ${ }^{32}$ According to Robinson, ${ }^{32}$ the dominant premise of the medical profession was that physicians were not self-interested and that competition was not necessary for further informed choice, cost control, and other health policy goals. Antitrust doctrine rejects the premise that any producer group can arbitrate price and quality and insists that such matters be decided by consumers themselves through choice among competing providers. ${ }^{17}$ Without this decision, it seems clear that the nation would have had to endure a longer wait for private innovations to make providers accountable to consumers for the cost as well as the quality of medical care. More likely, without antitrust enforcement, government would have assumed the dominant role in US health care. ${ }^{32}$ The competitive solution, however, may not be precluded by an alternative response in which central regulatory control is substituted for decentralized market oversight.

\section{Preemption of State Law}

The enactment in 1974 of the ERISA ${ }^{47}$ has had profound effects on the course of US health care. Its prime impact has been to preempt state laws "insofar as they may now or hereafter relate to any employee [health] benefit plan." This federal act remains a serious impediment to many state regulatory mechanisms and inhibits lawsuits against employers or organized health plans regarding employee health-benefit problems. The ERISA provides very little regulatory control over employee health plans. Its effect in limiting the ability of state law to deal with health plans was unintended, as it was significant in shaping the industry's course. ${ }^{16}$ Although the ERISA was enacted to combat fraud in employee pension systems, Congress did not consider it to relate to health care in any fashion. ${ }^{34}$ Eventually the ERISA had important unintended consequences in health care. For one thing, it caused nearly all appropriately-sized employers to self-insure their health benefits, because the ERISA's preemptive provisions allowed self-insured plans, alone, to avoid the load 
of state insurance regulation and the thrust of other state laws relating to health insurers. ${ }^{34}$ The law inadvertently enhanced the role of employers in procuring health coverage. The need, however, for an employer to self-insure to qualify for the ERISA preemption limited the act's value to small employers; the latter must obtain employee-related coverage from a health insurer or HMO that is subject to state law, which raises the cost of coverage and, for some, makes the cost prohibitive. ${ }^{16}$ Havighurst ${ }^{16}$ has indicated, however, that the revolution that began in American health care in the late 1970s would have been less profound if the ERISA-protected health plans had not been free from regulatory restraints and thus able to espouse novel approaches in the design and administration of health benefits.

\section{Corporate Responsibility for Medical Care}

In a 1966 case another important law-related policy change, which was out of public view, occurred. ${ }^{16}$ For the first time, in Darling v. Charleston Memorial Hospital, it was recognized that health care institutions have direct legal responsibilities to patients for the quality of medical care provided by independent physician contractors. Essentially the court held that the jury could find the hospital negligent itself for negligent treatment provided by a staff ER physician to a patient. At that time, professionalism and general antipathy to the corporate practice of medicine were the prevalent background notions against which this surprising decision to hold a hospital accountable for supervising a physician's treatment played out. The law recognized that corporations, as well as individual professionals, may have direct obligations to patients and, thus, to supervise the professional activities of affiliated physicians. In the present health care environment, corporate or institutional responsibility is recognized. The old model, however, continues to influence legal policy and professional thinking.

With this as background I will now summarize some of the major topics of law currently affecting neurosurgeons. This is an outline of a highly complex set of concepts and statutes.

\section{SIGNIFICANT STATUES IN RELATION TO NEUROSURGERY}

\section{Emergency Medical Treatment and Labor Act}

Even though the public has not seen fit to fund universal entitlement to health care, the legal system regularly gives patients legally enforceable rights to receive health services. A leading example of an unfunded entitlement to health care at the expense of private providers is the EMTALA.

In 1985, Congress enacted the federal "antidumping" provision as Section 1867 of the Social Security Act. Although the EMTALA only covered four pages of "miscellaneous provisions" in the huge Consolidated Omnibus Budget Reconciliation Act, ${ }^{10}$ it is itself, often referred to as COBRA. The law was amended in 1989 and 1991 and final regulations were published in 1994. Although it goes by many names, there is only one that substantively governs emergency care. A 1989 amendment, among oth- er things, eliminated all references to the term "active" when describing labor. ${ }^{28}$ Congress passed the EMTALA because of the widespread belief that private hospitals were "dumping" indigent or uninsured patients, denying them emergency care or transferring them to public hospitals for economic reasons, even though the private hospitals were fully capable of providing appropriate medical care. $^{25}$ The EMTALA was the congressional answer to the absence of health care for the indigent and uninsured. Representative Pete Stark of California, one of the leading proponents of the EMTALA said, "Patient dumping is but a symptom of a much larger problem. Thirty seven million Americans are without health insurance. Low income sick people are finding it increasingly difficult to get needed health care, and the burden of caring for them is falling on fewer and fewer hospitals." "Members of Congress also realized the significant financial burden it was placing on private hospitals. Senator David Durenberger said, "Access should be the government's responsibility at the federal, state and local levels. We cannot and should not expect hospitals to be this nation's $\mathrm{Na}$ tional Health Service." 9 By enacting the EMTALA, however, Congress decreed universal access for all and forced health care providers to assume fiscal responsibility for care of the poor under threat of fines, civil liability, or loss of participation in the Medicare and Medicaid programs. ${ }^{5}$

The EMTALA used the Medicare statute, for the first time, to define a standard of care for hospital emergency services and to regulate directly the delivery of care to non-Medicare patients. ${ }^{5}$ It created for citizens a federal right to emergency care. Congressional amendments in 1989 and 1991, regulatory expansion, and court-related interpretations of the law have made the scope of the EMTALA so broad that today most of its provisions have little, if anything, to do with economically driven patient transfers. The EMTALA now governs virtually all aspects of a hospital's delivery of emergency services, not simply in the emergency department but throughout the hospital. The law applies not only to ER physicians but to all members of the medical staff, particularly those who answer calls for the emergency department, and any member of the staff who admits or discharges patients from the hospital. ${ }^{6}$

Hospitals are now responsible for the actions taken by all members of their medical staff. They are no longer a place in which physicians practice medicine. Under the EMTALA, hospitals undertake medical practice, and they have a duty to control all medical staff members who may not be willing to provide on-call services or accept patients in transfer on the hospital's behalf. ${ }^{26}$ This, of course, follows from Darling v. Charleston Memorial Hospital and its affirmation of corporate control over physician practice. ${ }^{16}$ The EMTALA represents an anomalous right to emergency health care, a giant unfunded mandate, providing far more than a guarantee of emergency department care. It is, in essence, catastrophic health care coverage for any US resident who does not have insurance coverage or the ability to pay. ${ }^{6}$ Still in existence are the underlying reasons the EMTALA was passed and the reasons it requires ongoing enforcement-the substantial and everincreasing amount of uncompensated care. As Bitterman ${ }^{6}$ 
has asserted, in his precise treatment of its statutes, the EMTALA is not going to go away. In his view, if anything, it will be strengthened, enlarged, and enforced with even more vigor.

\section{Fraud and Abuse Laws}

There are four points of focus related to this material. ${ }^{24}$ 1) Fraud and abuse laws permit most legitimate transactions-those in which there is a legitimate business purpose other than the generation of patient referrals. Nevertheless, careful documentation is necessary in all instances. 2) Good documentation will not save a bad transaction. Regardless of how it is documented, a transaction that lacks an independent business purpose unrelated to the generation of referrals is illegal. The fraud and abuse laws are broadly worded to identify all such arrangements. 3) Academic medical centers are not exempt from fraud and abuse laws. Business arrangements within an academic medical center are not exempt from fraud and abuse laws. State and federal antikickback laws include no exemption for academic medical centers, and there have been many recent enforcement actions against these facilities. In the Stark "Self-Referral Law" certain transactions by academic medical centers are exempted if they qualify for a narrow exemption. 4) Beware of "whistleblowers." Competitors or former employees are probably more likely than a government agency to enforce fraud and abuse laws against a physician, often in the form of a private whistleblower suit. These private actions can be as protracted and expensive to resolve as a government investigation and prosecution. Law firms now advertise in nursing journals searching for possible plantiffs.

The laws covering fraud and abuse have proliferated and broadly proscribe activities, some of which may have been undertaken in good faith. ${ }^{14}$ Depending on the law, and sometimes the discretion of the prosecutors, violations may be punished by criminal penalties, civil penalties, or mandatory or discretionary exclusion. An exclusion means that no Medicare or other federal or state health care program payment will be made for services 1) rendered by the excluded physician, or 2) directed or prescribed by an excluded physician. ${ }^{48}$ There is no doubt that penalties are severe. Little needs to be said about how imprisonment affects one's life. Similarly, the hardship imposed by large monetary fines is well known. What is not as clear is that exclusion from one of the federal programs can be devastating. An exclusion sanction damages a physician's professional practice and reputation, directly impacting one's ability to maintain medical staff privileges, to contract with managed care plans, to obtain professional liability insurance, and to maintain relationships and patterns of practice for the referrals of any patients whatsoever. ${ }^{14}$ The law prohibits any Medicare provider from billing for any services that were rendered at the direction or on the prescription of a physician excluded from the Medicare program. ${ }^{49}$ Physicians and hospitals, knowing that they would be denied reimbursement because a practitioner has been excluded from the Medicare program, would likely refuse to provide services to beneficiaries being treated by an excluded provider. In such circumstances this type of a sanction may prevent a physician practicing medicine. Moreover, although a monetary sanction might seem like a lesser penalty, such may not be the case. ${ }^{14}$ The Department of HHS OIG is authorized to exclude any individual who commits an act that is punishable as a criminal offense or a monetary penalty. ${ }^{38}$

There are concepts common to fraud and abuse laws. All are intended to prevent an individual's financial considerations from compromising independent medical decision making. Two broad concepts stand out in the interpretation and enforcement history under each of these laws. ${ }^{24} 1$ ) There is no relationship permitted between compensation and referral. All fraud and abuse laws prohibit compensation structures in which the amount of payment is varied according to the volume of actual or promised referrals by the compensated party. A hospital, for example, may not offer a guaranteed income to a recruited physician in which there is a formula that increases income proportionately with the volume of the practitioner's referrals to the hospital. 2) A transaction cannot be judged by interpretation of documents alone. It is possible to judge the legality of a particular transaction only by reviewing all of the facts and circumstances that surround the arrangement. Although the actual terms of the transaction are very important to these efforts, the relationship between the participants, their referral history, and any other circumstances which may bear on the likelihood of future abuse, are also critical. Objective, expert assessment of transaction-related facts and circumstances is imperative so it is not possible to "paper over" illegal transactions by use of deceptively clean, but false, documentation.

On the surface it is hard to argue against law enforcement directed at Medicare fraud and abuse. The annual costs of Medicare-related fraud and abuse are huge. Since the early 1990s when the government began a serious enforcement effort, law enforcement agencies have reported billions of dollars of annual program savings. The trustees of the Medicare Trust Funds have stated that fraud and abuse enforcement in recent years has increased the period of time over which the funds can remain solvent. ${ }^{38}$ On the other hand, such enforcement has generated a substantial backlash among Medicare providers. Some middle ground is needed so that the legitimate concerns of providers who become entangled in an aggressive antifraud net can be addressed. ${ }^{38}$

Federal Medicare and Medicaid law provides for both civil and criminal sanctions against perpetrators who violate provisions that Congress has loosely categorized as "fraud and abuse." Certain provisions go far beyond traditional concepts of fraud. Neurosurgeons need to be sufficiently aware of these laws to avoid the risk of sanctions. Because these laws are complex and violations can result in serious penalties, neurosurgeons may want to seek the advice of their attorneys to ensure compliance.

\section{Kickbacks and Rebates}

The knowing and willful solicitation, offer, payment, or receipt of any remuneration, which is broadly defined to encompass virtually anything of value, whether direct or indirect, in cash or in kind, in return for 1) the referral of a patient receiving benefits under a federal health care program or 2) the purchase, lease, order, or arrangement (or recommendation of the same) of any item or service 


\section{J. A. Kusske}

paid in whole or in part under a federal health care program, is punishable as a felony. ${ }^{50}$ The Federal Anti-Kickback Law specifically covers all aspects of remuneration including solicitation of remuneration for referrals, receipt of remuneration for referrals, offers of remuneration for referrals, and payment of remuneration, for referrals. ${ }^{51}$ The law prohibits any remuneration including any kickback, bribe, or rebate. Consequently, a party cannot avoid liability by characterizing payment in innocuous terms if its real purpose was to compensate for referrals.

Because of the breadth of the Federal Anti-Kickback Law, the statute applies to all participants in a transaction, typically including physicians. Regulators routinely target physicians in fraud investigations, in part because their involvement in fraudulent schemes is relatively easy to prove. ${ }^{14}$ The lay business partners of physicians, including hospitals, individual executives, and health care consultants such as attorneys, are also targets.

Enforcement of the Federal Anti-Kickback Laws is multifaceted. Violation is a criminal offense with statutory penalties including fines up to $\$ 25,000$ and imprisonment for up to 5 years for each violation. Convicted providers are excluded from participation in all federal programs for up to 5 years. There may be the imposition of civil monetary penalties of up to $\$ 50,000$, in addition to damages up to threefold the total amount of illegal remuneration. ${ }^{52}$ A private citizen may attempt to enforce the Federal Anti-Kickback Law as a "whistleblower" in a civil "qui tam" action. More recently, some courts have ruled that a party may submit a false claim in violation of the Federal FCA. ${ }^{53}$

\section{Professional Courtesy}

"Professional courtesy" is an issue with which most neurosurgeons are frequently involved. Professional courtesy is understood to include not only the waiver of all or part of a fee for services provided to a physician's office staff, other physicians, and/or their office families, but also the waiver of coinsurance obligations or other obligations for these individuals. ${ }^{15}$ The OIG in its "Compliance Program Guidance for Individual and Small Group Practices" 29 provided considerable comment concerning the circumstances under which "professional courtesy" could result in illegal remuneration under federal law. The OIG believes that courtesy services result in prohibited kickbacks when they are given with the intent of influencing physician referrals of Medicare and Medicaid patients. The OIG has asserted that whether a professional courtesy arrangement is viewed as a violation of fraud and abuse laws is determined by how the recipient of professional courtesy is selected. Thus, if the recipients are selected in a manner that directly or indirectly takes into account their ability to affect past or future referrals, the antikickback statute may be implicated. On the other hand, if the physician is not in a position to refer patients, antikickback considerations should not be raised. ${ }^{29}$

Additionally if the professional courtesy is extended through a waiver of copayment obligations, other statutes may be implicated, including the prohibition of inducements to beneficiaries. ${ }^{54}$ These provisions provide heavy penalties for physicians who offer or give anything of value, such as a waiver of copayment, to a Medicare or Med- icaid beneficiary that the physician knows or should know is likely to influence the individual to order or receive items or services. This provision makes it very difficult for a neurosurgeon to provide any professional courtesy services to physicians, their staff, or families who also happens to be Medicare or Medicaid beneficiaries.

A neurosurgeon who routinely waives copayments could be in serious trouble because of Medicare and Medicaid regulations. Congress has passed specific statutes to prohibit waivers of copayments in most cases. Physicians who offer or give anything of value to a Medicare or Medicaid beneficiary that the "person knows or should know is likely to influence such individual" to order or receive items or services will be subject, in addition to such other penalties as may be assessed by law, to a civil monetary penalty of not more than $\$ 10,000$ for each item or service provided or an assessment of not more than three-fold the amount claimed. ${ }^{54}$ Congress has further stipulated that "the waiver of coinsurance and deductible amounts (or any part thereof), transfers of items and services for free, or for other than fair market value" are items of remuneration that trigger the statute..$^{54}$

\section{False Claims Act}

The existence of the FCA long predates the Centers for Medicare and Medicaid Services, previously called the Health Care Finance Administration and Medicare. The act became law in 1863, during the Civil War, as a tool to allow the government to deal with cheating by defense contractors. The FCA allows the government to bring a civil action to deal with false claims in which the party had actual knowledge, reckless disregard, or conscious disregard of the falsity of the claim. ${ }^{53}$ Thus, the term Medicare fraud often includes not only intentional false statements but also those that are reckless or deliberately indifferent to the truth. For criminal penalties to apply, the government must prove beyond a reasonable doubt that there has been criminal intent to defraud. This is a difficult standard to meet. ${ }^{38}$

The government has assured providers that the statutory standard is much different from negligent errors or mistakes. The chief counsel to HHS OIG has written that the "The False Claims Act simply does not cover mistakes, errors or negligence." ${ }^{41}$

The act permits private citizens to sue on behalf of the government, in so-called qui tam actions, and to obtain a percentage of any recovered funds. A qui tam action is a civil, statutory proceeding brought by a third party to redress a wrong against an institution. The plaintiff sues "as well" for the institution as for him/herself..$^{38}$ Qui tam relators are also called "whistleblowers." In 1986 Congress modified the FCA with amendments that strengthened it. These amendments clarified that the act applied to Medicare and Medicaid; it facilitated the ability of private parties, called "relators," to bring cases on the government's behalf. The 1986 amendments were part of a series of laws that Congress enacted to enhance fraud and abuse enforcement, particularly as it related to Medicare. ${ }^{12}$

In recent years private parties and the government have brought FCA cases in a broad range of contexts but especially against defense contractors and providers of health care. The act provides a critical tool with which govern- 
ment attorneys can crack down on fraud and abuse in health care programs. To providers, however, it is one of the government's most feared weapons against alleged fraud because of the range of substantial potential penalties. $^{38}$

Most of the government's FCA cases are generated by private whistleblowers. As Stanton ${ }^{38}$ has asserted, a relator begins the qui tam action by filing a complaint in secret in federal court and, at the same time, delivering a copy of the complaint and supporting evidence to the Department of Justice. The complaint is not served at first on the respondent. Through HHS, OIG, or the Federal Bureau of Investigation the case is then investigated and a determination is made whether to intervene. If the government does intervene, it assumes full responsibility for the litigation, although the relator remains a party. ${ }^{38}$ Qui tam actions offer a successful relator the prospect of significant recoveries. ${ }^{36}$ The process of prosecuting a case, however, can be painful for the relator. As one attorney has conveyed, "It is common for relators to suffer severe financial, social and/or personal consequences." 44

A FCA case is a serious threat to a respondent. Respondents have a strong incentive to settle FCA cases with the government rather than fight. Under the act, a party is liable for triple damages and penalties up to $\$ 10,000$ per false claim. As applied to Medicare, each false claim is an individual billing to Medicare for a specific medical service or item. The potential penalties can mount quickly. Additionally, the government can suspend or delay payment of later claims once a respondent is alleged to have submitted some claims falsely. ${ }^{38}$

Of great interest is the assertion by Stanton ${ }^{38}$ that from the enforcement agency's perspective, resources are so limited that without settlements, the government would be unlikely to prevail in many cases, regardless of merit. In terms of serving justice, the government's inability to prosecute any large number of cases in court as well as the tendency of cases to settle rather than go to court, have serious consequences for the perception of legitimacy of the process. ${ }^{38}$ The problem, as Stanton points out, is that when the OIG and Department of Justice pursues a FCA case, they are likely to receive a settlement whether or not the respondent feels actually culpable. Consider the recent Physician at Teaching Hospitals audits by the OIG and the number of teaching institutions that settled rather than litigate in court. Attorneys who are forced to settle cases for fear of penalties express great resentment. In terms of the government's interests, the ability to obtain a settlement in virtually any reasonable case involving the FCA raises the specter that the patterns of true Medicare fraud may be different from the pattern of cases that the government settles. ${ }^{38}$

It has been stated that much of the fraud in health care, and in Medicare in particular, is not easily detected. ${ }^{37}$ As Sparrow ${ }^{37}$ has noted, a perpetrator of fraud might take special care to submit false claims that superficially appear appropriate and well documented to avoid triggering a review. Sparrow has asserted that government lacks the necessary understanding of the incidence and severity of different types of fraud. He believes that much more work is needed to gather quantitatively sound information about fraud; health care fraud has not been brought under con- trol because the industry has underestimated the complexity of the fraud-control business and has developed no reasonable defenses against it. Electronic claims, he argued, will make the situation much worse unless serious and urgent attention is paid to the provision of prudent controls.

\section{Office of the Inspector General and the Physician}

As the police for the Medicare program, the Department of HHS OIG is intent on ridding the Medicare system of abusers, including physicians. ${ }^{21}$ One can no longer assume that only unscrupulous colleagues will be the subject of OIG inquiries and investigations. Nearly any physician who provides services to Medicare patients can become involved directly or indirectly in an OIG investigation. ${ }^{21}$ The OIG does not limit its investigations to the most egregious cases. Those involving less flagrant abuses are used as examples to deter physicians from testing the outer limits of Medicare statutes, regulations, and guidelines. $^{21}$

The OIG has a broad mandate to conduct activities to protect the economy and efficiency of the Medicare program. It is authorized to direct and coordinate investigation into allegations of potential Medicare fraud. In addition, it can investigate cases of suspected criminal fraud, prosecute civil fraud and civil monetary penalty cases, and participate in negotiating settlements to avoid court proceedings. ${ }^{21}$ It can impose administrative sanctions, which include exclusion of physicians from program participation.

The way in which recent OIG investigations of physicians and other providers of Medicare services have come about leaves almost any practicing physician open to a visit from an OIG investigator. ${ }^{21}$ For example, a physician who believes he/she is abiding by applicable Medicare billing guidelines may be inclined to report to the OIG another physician's billing practices that appear to violate Medicare rules. Whistleblowers are armed with significant financial incentives to identify physicians who are suspected of submitting false health care claims. Even the most prominent and reputable physicians have not been invulnerable to investigations instigated by whistleblowers who, in some cases, function as bounty hunters. ${ }^{21}$ Many OIG inquiries are initiated during Medicare payment audits conducted by Medicare carriers. A group of voluntary or involuntary sources of information exists, including disgruntled or terminated employees, jilted lovers, third-party administrators for insurance companies, Medicare beneficiaries, and overzealous marketing personnel who aggressively try to create new business for their health care employers.

As Hooper ${ }^{21}$ has noted, the OIG investigations and inquiries regarding physicians' billing practices and billings will likely increase over the next several months and years. Neurosurgeons should fully understand their rights with respect to such investigations and should have procedures in place to respond to inquiries or investigation if they occur.

\section{Self-Referral Prohibitions}

This law and the accompanying regulations, at their most basic, prohibit physicians from referring Medicare/ 


\section{J. A. Kusske}

Medicaid patients to entities for certain designated services with which they, physicians, have a financial relationship and billing for these services-unless a specific exception applies. The self-referral provisions presume there is an ethical dilemma whenever a physician refers a patient to an entity in which he/she has a financial interest. The statutes are commonly known as the Stark laws.

Named for California Representative Fortney H. "Pete" Stark, the first Stark law was passed in 1989 and is commonly referred to as "Stark I." ${ }^{2}$ Stark I prohibited a physician from ordering a clinical laboratory test or service from an entity with which the physician, or an immediate family member, had a financial relationship, if the cost of the test is reimbursable by Medicare. The law encompassed investment interests and compensation arrangements. ${ }^{42}$ The concept of referral was broadly defined to include any order for a service. Because of its breadth, the statute included a number of exceptions, which has made the law notoriously difficult to apply. Stark I became effective January 1, 1992, and the final regulations implementing those provisions were published in August 1995. The Stark law was amended in 1993, and the amendments are commonly referred to as "Stark II." 55 Stark II extended the referral prohibition to services reimbursable under Medicaid and greatly expanded the list of items and services covered by the law-the so-called DHSs. Stark II became effective on January 1, 1995. On January 4, 2001, the Health Care Finance Administration, now the Centers for Medicare and Medicaid Services, issued Phase 1 of the final Stark II regulations and the final rule became effective January 4, 2002. ${ }^{56}$ The "final" rules we see are actually somewhat less than final. The new rules deal with only parts of the Stark II law. They include interpretation of the basic self-referral prohibition, the global exceptions, statutory definitions, and exceptions for selected compensation arrangements. ${ }^{56}$ Overall, Stark II bars physicians from referring patients for any of 11 DHSs to entities in which they or their families have a financial interest unless an exception applies. In Stark II it is also stated that entities that provide designated health services may not bill Medicare, Medicaid, third-party payers, or any individual, including the recipient of the service, for such referred services. ${ }^{56}$

Neurosurgeons now must be certain that their business practices accord with physician self-referral final rules that aim to prevent doctors from profiting from sending Medicare patients for medical services.

Definitions, in the context of Stark I and II, are all important because they play a central role in determining whether certain providers, practices, or situations fall under its provisions. ${ }^{39}$ Neurosurgeons would be wise not to assume they are covered or excepted under Stark laws until reading the definitions of key terms. There are five definitions central to these self-referral regulations because, together, they define what individual and organizations Stark affects: 1) DHS, 2) entity, 3) physician, 4) referral, and 5) remuneration. If you meet these definitions as an entity or physician or if a transaction involves a referral or remuneration for a DHS under these definitions, what you do may be prohibited by Stark or allowed by a Stark exception..$^{39}$

The DHSs include the following: ${ }^{57}$ clinical laboratory services; physician therapy services; occupational therapy services; radiology and certain other imaging services; radiation therapy; durable medical equipment; parenteral and enteral nutrients, equipment and supplies; prosthetics, orthotics, and prosthetic devices and supplies; home health services; outpatient prescription drugs; and inpatient and outpatient hospital services.

An entity is defined as any independent physician practice, group practice, independent proprietorship, trust, corporation, partnership, foundation, not-for-profit corporation, or unincorporated association that furnishes any of the Stark-designated services. ${ }^{57}$ Accordingly, an entity is not the referring physician; rather, it is the physician's practice. ${ }^{39}$ Stark's prohibition on referrals applies only to those made by physicians, not to referrals made by nonphysicians. Stark defines physicians to include doctors of medicine, osteopaths, dentists, podiatrists, optometrists, and chiropractors.

A referral is defined as a request, order, certification or recertification by a physician for someone else to provide any of the 11 Stark-DHSs for which Medicare pays. Stark permits physicians to refer clients to themselves because a referral to oneself is not a referral if the referring physician personally performs the service. A referral to one's own practice, however, is considered a referral. ${ }^{56,57}$ The final rule defines referral in part as "a request by a physician for ordering of or certifying or recertifying the need for any designated health service for which payment may be made under Medicare Part B, including a request for consultation with another physician, and any test or procedure ordered by or under the supervision of that other physician but not including any designated health service personally performed or provided by the referring physician. A designated health service is not personally performed or provided by a referring physician if it is performed or provided by any other person including but not limited to the referring physician's employees, independent contractors, or group practice members..."

Remuneration, for the purposes of Stark, is any payment made directly or indirectly, overtly or covertly, in cash or in kind..$^{57}$

When considering the legality of existing or potential business ventures, neurosurgeons should first consider whether an arrangement is prohibited by the self-referral prohibitions. The antikickback laws are only relevant in cases in which the arrangement does not involve a prohibited self-referral. Both sets of laws deal with referrals and both target financial relationships that may benefit from referrals. ${ }^{39}$ There are marked differences, however. Stark deals with providers referring patients to other practices in which they have a previously developed financial involvement. The Anti-Kickback Statute deals with providers who refer patients to providers, regardless of preexisting financial relationship, in exchange for some kind of return. ${ }^{39}$ Stark laws contain fact-based rather than intent-based regulations. Under Stark, it does not matter what you intended to do-if you are in violation, you're in violation, even if it was an innocent mistake. The AntiKickback Statute, which is intent based, requires the government to prove that you willfully and intentionally sought to violate its terms. ${ }^{39}$

Stark and the Anti-Kickback Statute are both similar 
and different in terms of the legal loopholes created to permit certain activities or situations. Under Stark, these provisions are called "exceptions" and under the Anti-Kickback Statute they are called "safe harbors." Because Stark is based on fact rather than intent, a physician is automatically in violation of Stark if he/she has a prohibited financial relationship — that is, unless an exception applies. Under the Anti-Kickback Statute, although a physician is in the clear if his/her situation falls within a safe harbor, he/she may also be in the clear even if the arrangement does not fit within one. In short, under Stark, exceptions are required, whereas under the Anti-Kickback Statute, safe harbors are not mandatory, but are a guarantee of safety if the physician's behavior happens to fall within one and if that behavior complies with all other applicable regulations. ${ }^{39}$

Sanctions apply to violations of Stark. ${ }^{55}$ These include denial of payment, refunds, civil money penalty, assessment and exclusion, and civil money penalty and exclusion for schemes to circumvent the law.

Neurosurgeons should seek an advisory opinion from HHS. Federal law mandates that formal guidance is provided regarding application of, among other things, the antikickback statute and safe harbor provisions, as well as self-referral laws. The HIPAA of 1996 requires the issuance of opinions regarding the following: what constitutes illegal remuneration under the antikickback law; whether an arrangement falls within a statutory exception or a safe harbor under the antikickback law; what constitutes an inducement to reduce or limit services under the antikickback law; and whether any particular activity constitutes grounds for penalties under the antikickback law, civil monetary penalties, or exclusion statutes.

The regulations set forth the procedure for requesting and responding to a request for an advisory opinion. ${ }^{58,59}$ Only parties to the arrangement may submit a request, and requests must relate to an existing arrangement or one the requester in good faith plans to undertake. ${ }^{60}$

\section{Employment Retirement Income Security Act}

Compared with the ERISA, few federal laws have a greater impact on the operations of MCOs. Although the ERISA does not directly regulate most MCOs, it does regulate employer-sponsored employee benefit programs to which MCOs market their product. ${ }^{34}$ The ERISA will affect the nature, design, and administration of such products by MCOs. Moreover, this act will determine what state laws can be applied to such products, as well as what legal challenges can be made to the administration of such products.

Neurosurgeons should be aware that a nongovernment employer-maintained plan that provides health care or health care benefits to employees, including plans providing coverage or benefits through a managed care arrangement, generally constitutes an employee benefit plan subject to the ERISA. ${ }^{61}$ Every ERISA-governed employee benefit plan is required to be set forth in a written plan document that outlines its provisions governing health benefits. ${ }^{62}$ This usually is accompanied by a description booklet that summarizes the plan's operative provisions in lay language. The Department of Labor has prescribed the types of information that are required to be included in the summary plan description. ${ }^{63}$ The ERISA provides little regulation to govern the content of employee health benefit plans. Despite this, ERISA's impact is considerable.

Of paramount importance is the ERISA's preemption of all state laws, as well as state law causes of action, that relate to its plans. ${ }^{64}$ This preemptive scope provides plan sponsors with great flexibility regarding the design of benefit programs, because the ERISA generally will preempt state law attempts to regulate the terms and conditions of the ERISA plans. ${ }^{34}$

Historically, most managed care programs were insured arrangements that were subject to state laws regulating the business of insurance. Presently increasing numbers of plan sponsors have adopted self-insurance arrangements that incorporate a preferred provider organization, pointof-service product, or other features generally associated with the rubric of managed care. The key here is that a self-insured, or self-funded, plan does not purchase insurance, however, and a provision of the ERISA known as the "deemer clause" prevents a state from directly applying its insurance regulation to the employee health plan. ${ }^{34,65}$ A state may not directly or indirectly regulate the terms and conditions of a self-insured plan.

Arguably, no provision of the ERISA has more effect on operations of MCOs than the preemption clause. Congress enacted the following three clauses relating to the preemptive effect of ERISA: 1) the preemption clause, ${ }^{66}$ 2 ) the savings clause, ${ }^{67}$ and 3 ) the deemer clause. ${ }^{68}$ The preemption clause simply states that the ERISA supersedes any and all state laws insofar as they may be related to any ERISA-governed employee benefit plan, except to the extent that such laws may be "saved" from preemption by the savings clause. This clause preserves from preemption any state law that regulates insurance, banking, or securities, except as provided in the deemer clause. This clause provides that an employee benefit plan, including health plans, shall not be deemed to be an insurance company or other insurer or to be engaged in the business of insurance or banking for the purposes of any state law purporting to regulate insurance companies or insurance contracts. All state-related power to regulate insurancereserved under the savings clause-is taken away with respect to self-insured plans under the deemer clause. ${ }^{34}$ This interpretation establishes a disparity between the regulation of insured (answerable to state law) and uninsured (self-funded) plans. The US Supreme Court issued a decision that such a dichotomy was the intent of Congress when it enacted the statute. ${ }^{34}$ The net effect of this on practicing neurosurgeons is related to the following categories, specifically: utilization review, credentialing decisions, vicarious liability for medical malpractice, and negligent representations by MCOs to providers.

The consensus among courts seems to be that MCO's utilization review decisions, even when they involve medical decisions, are integral parts of the administration of the ERISA plans. Consequently, they relate to such plans and are preempted by the ERISA. The US Court of Appeals for the sixth district reaffirmed this conclusion. ${ }^{69}$ This occurred in a case in which a patient committed suicide; following this, the individual's heirs sued, among others, the patient's ERISA plan administrator, the plan's mental health utilization review committee, and the psy- 


\section{J. A. Kusske}

chologists performing utilization review on behalf of the plan, alleging that the plan administrator wrongfully denied benefits for inpatient psychiatric care based on the utilization review company's failure to authorize such care. Plaintiffs' state law claims based on such utilization review decisions included wrongful death, improper refusal to authorize benefits, medical malpractice, and insurance bad faith. The court held that such claims clearly related to the ERISA plan and were preempted by ERISA. This decision relied on an earlier decision rendered by the US Court of Appeals for the Fifth Circuit. ${ }^{70}$ In that decision, dealing with the death of a fetus, the court acknowledged that utilization reviewers make medical decisions despite any disclaimers to the contrary in policy manuals or promotional materials. The court found that because the wrongful death claim was related to a denial of plan-related benefits, it was preempted by the ERISA. Other courts have followed the reasoning of the Fifth Circuit ruling and have preempted claims arising out of utilization review decisions.

With reference to the ERISA, courts have also ruled on credentialing-related decisions. Cases have been focused not on the nature or extent of the investigation of a provider's qualifications but rather on whether a claim that an MCO did not conduct requisite investigation is preempted by the ERISA. Most courts faced with this issue, have ruled in favor of the ERISA preemption. ${ }^{34}$ Managed care organizations take comfort in the likely preemption of claims in which an MCO has been charged with negligently selecting or retaining a participating provider who committed malpractice.

In recent years, an area of intense legal debate has been the assertion of MCO-related "vicarious liability"-that is, the extent of their medical malpractice culpability for health care providers to whom they refer patients. In such cases, a common allegation is that the patient reasonably relied on actions of the MCO, which offered, or "held out," the negligent provider as its employee or agent; here, the degree of reliance required of the patient is subject to judicial debate. ${ }^{34}$ As in the area of negligent credentialing, the ERISA plays a critical role in determining whether an MCO will be vicariously liable for the malpractice of the health care provider. The courts, however, have been sharply divided as to whether the ERISA preempts such claims. Courts holding that MCO-directed claims of medical malpractice are not preempted have found that such claims do not sufficiently relate to the employee plan to warrant preemption. In such decisions, courts point out that such claims do not involve the administration of benefits or the level or quality of benefits provided under the plan; they merely allege negligence by a physician-agency relationship between the physician and the MCO. ${ }^{34}$

Courts in which the opposite conclusion is reached have reasoned that a vicarious liability malpractice claim concerns the delivery of benefits under the ERISA plan and that the claim requires examination in terms of the ERISA plan to determine quality and quantity of services required of physicians and the relationship between the ERISA plan and the physician. ${ }^{34}$ Although the lower courts have been almost evenly divided as to whether the ERISA preempts medical malpractice claims against MCOs based on vicarious liability theories, two Circuit Court decisions in the mid-1990s indicate that the trend may be away from preemption. ${ }^{71,72}$

The ERISA can affect many of the core functions of an $\mathrm{MCO}$, from product design to administration to issues of legal liability. Accordingly, neurosurgeons need to be aware of the far-reaching effects of this statute, as well as the rapidly developing body of case law, which bear directly on their practice patterns and reimbursement issues.

\section{Antitrust Law}

Physicians have been told on countless occasions of the perils of antitrust laws and how specifically they prevent them from competing in the marketplace. ${ }^{13}$ To be sure, the antitrust laws pose strong barriers, and some argue they are in need of reform even after the August 1996 Guidelines, in which the federal antitrust enforcement agencies, the Federal Trade Commission and the Department of Justice moderated their approach to antitrust review of collective activity by physicians. ${ }^{40}$ In addition to antitrust sanctions physicians have been concerned about unionization.

Typically, unionization is not an option for most physicians. ${ }^{13}$ Under current federal law, the only physicians that can unionize and collectively negotiate are employed physicians that hold nonsupervisory positions. Self-employed physicians in independent practice are not entitled to the protection of the National Labor Relations Act and thus may not collectively bargain with health plans. ${ }^{13}$ To negotiate lawfully as a group, independent physicians must be organized in a network in which they share substantial financial risk or in which substantial clinical or functional integration exists.

The basic objective of the antitrust laws is to protect the free market. Business practices that interfere with free competition should be eliminated so that each business has a fair opportunity to compete on the basis of price, quality, and service. The law prohibits conduct associated with unreasonably anticompetitive effects. ${ }^{13}$ There are a number of antitrust statutes that have application in the health care area. The most relevant one for physicians is Section 1 of the Sherman Act, which provides: "Every contract, combination in the form of trust or otherwise, or conspiracy, in restraint of trade or commerce among the several states, or with foreign nations, is declared to be illegal." ${ }^{13}$ Penalties for violating the antitrust laws are significant. Criminal violations of the Sherman Act are tried as felonies, and a criminal conviction virtually ensures civil liability. Financial judgments for civil violations may run in the millions, particularly because a private party can recover three times the amount of damages actually sustained as well as other costs incurred in prosecuting the case. ${ }^{13}$

To prevail in a Section 1 action, the existence of a "contract, combination or conspiracy" first must be established. Such agreements need not be in writing nor do they need to be the result of a formal understanding. An implied understanding may be enough and a "knowing wink can mean more than words." Thus, for example, at a medical society meeting, competing physicians engage in informal discussion in which they express dissatisfaction about an MCO's decision to reduce fees, followed by en masse withdrawal of physicians from the MCO, could be 
successfully prosecuted under antitrust law. ${ }^{13}$ Furthermore, a physician, even independently, should not use the threat of collaborative action to enhance his or her bargaining power. ${ }^{13}$

Other activities, which might generate an antitrust action, relate to restraint of trade. "Unreasonable" restraints are likely to be challenged in a civil lawsuit. These allegations often arise in the context of, for example, a denial of hospital privileges, an ethical norm relating to advertising, or standards of practice, or a standard of minimum qualifications for certification or membership. ${ }^{13}$ Courts in which the legality of a particular restraint is assessed do so under the "Rule of Reason." That is, they evaluate several factors including the nature of the restraint and whether it is related to reasonable objectives such as quality of care, its pro- and anticompetitive effects, its history, and its market conditions. ${ }^{13}$

"Illegal per se" restraints are always conclusively presumed to be anticompetitive. Such restraints include price fixing, certain group boycotts, and market allocations in which competitors divide a market among themselves. Price fixing includes agreements that in any way relate to price, even those that only indirectly affect price. These also are considered to be per se violations. ${ }^{13}$ Some examples include agreeing on minimum or maximum prices or establishing uniform terms of sale or discount policies. Group boycotts refer to situations in which competitors close access to a market necessary for competition, or in which boycotting competitors possess a dominant share of the market. Generally, boycotts formed for the purpose of enforcing a price-fixing scheme would be classified as "illegal per se." 13 An example of a group boycott includes agreeing to refuse to join an HMO unless it raises reimbursement rates. Market allocation refers to an allocation or division of markets between two or more actual or potential competitors. This too is illegal per se. An example includes an agreement between two competing medical groups that neither group will participate in an MCO in which the other has already contracted, thereby reducing competition within any MCO. ${ }^{13}$

Claims by physicians excluded from MCOs and other entities represent the largest number of antitrust challenges brought in the health care field. ${ }^{23}$ Typically, provider exclusion issues can arise in situations in which MCOs seek to limit the size and composition of their provider networks or in which they enter into exclusive contracts with provider groups and agree not to contract with competing groups. Neurosurgeons must realize that exclusionary conduct by single entities not controlled by providers presents little antitrust risk in most cases. This holds true even when the MCO has a dominant market position. ${ }^{4}$ In contrast, significant antitrust concerns may arise when the excluding entity is provider controlled or when the former agrees to the exclusion with other providers. In either case, an unlawful group boycott, constituting a violation of Section 1 , may be found. ${ }^{23}$

Neurosurgeons can take many actions under the antitrust laws. They need not sit by helplessly while the marketplace evolves around them. Despite their breadth, the antitrust laws do not prohibit all actions, and there are a number of legitimate strategies that can be followed. Section 1 only includes "contracts, combinations or con- spiracies" in restraint of trade. Because the provision only deals with collusive activities, activities undertaken by individuals or single entities do not raise Section 1 concerns. $^{13}$

Neurosurgeons are free to negotiate with individual payers on the specific price, quality, or other contract terms they believe to be appropriate. Individual physicians may also decide not to have a working relationship with a particular entity so long as the conduct represents an individual decision based on the physician's own judgment and not the physician's understanding of what other competing physicians do or plan to do. Further, provided they make independent decisions, individually competing physicians may commiserate over low fee schedules or may impugn the motives or integrity of health plans, assuming the physicians do not act collectively on their grievances. ${ }^{45}$

Neurosurgeons should also know that current law permits fully integrated medical groups to function for all purposes as a single entity. ${ }^{13}$ Thus, a fully integrated group, such as a professional medical corporation, may negotiate price terms and/or require its members to deal collectively with third-party payers without fear of antitrust liability. Medical groups are free to expand by employing more physicians and/or merging with one or more medical groups. The medical group, however, cannot become so large that it violates Section 2 of the Sherman Act, which prohibits monopolization or conspiracies to monopolize. ${ }^{13}$ Significantly, the Seventh Circuit Federal Appeals Court overturned a \$20 million judgment won by Blue Cross Blue Shield of Wisconsin and its HMO against the Marshfield Clinic. ${ }^{7}$ The court made a number of significant rulings concerning the ability of physicians to join and produce quality care at high prices. Among other issues, the court concluded that monopoly power could not be inferred from the clinic's practice of charging high prices or from its high rates of return, relative to the prices and rates of its competitors.

Neurosurgeons may contend with antitrust issues in other ways. An independent agent can assist them in their individual negotiations with third-party payers. The 1996 Guidelines liberalize permissible activities that a messenger may engage in by authorizing the messenger to receive from an individual physician the authority to accept contract offers on his/her behalf. ${ }^{40}$ For an in depth discussion of this issue, the 1996 Guidelines should be consulted.

Neurosurgeons can also create or join a physician network joint venture in which substantial risk is shared. The courts and the federal government have recognized that the formation of physician contracting networks can be procompetitive. The 1996 Guidelines provide expanded discussions of the antitrust principles that Department of Justice and Federal Trade Commission will apply when analyzing physician network joint ventures. ${ }^{40}$ The Guidelines specifically recognize the societal value of organized physician network joint ventures, such as independent practice associations, preferred provider organizations, and other forms of physician organizations marketing to health plans. An extensive review of the antitrust issues facing physicians, including a discussion about physician unions, is available, ${ }^{13}$ as is a review of the antitrust implications of provider exclusion from MCO networks. ${ }^{23}$

Finally, competition seems to be replacing collusion as 


\section{J. A. Kusske}

the modus operandi of the emerging health care marketplace. Some advice regarding caution is needed, however, lest the ever-present desire to merge create cartels in local physician, hospital, or insurance markets. Robinson ${ }^{33}$ has indicated his belief that antitrust enforcement is particularly important in health care. He pointed to the long record of landmark antitrust cases that bear witness to the anticompetitive and -consumer tendencies of medical societies, nonprofit hospitals, and Blue Cross insurers, as well as the more typical cast of for-profit suspects. He has asserted that the tendency to consolidate into local cartels will grow as the pressure on health care revenues intensifies. ${ }^{33}$

\section{Health Insurance Portability and Accountability Act}

I don't see the logic.... of how we could keep that confined to that aged group. The logic looks like once we have done this we are going to have to extend it further. That is why I think logically people say this will lead to socialized medicine, not saying those who advocate it are Socialists - I want to emphasize that again-but would lead to the technique of the Government moving heavily into the entire field of healthcare. 64-137)

Thomas B. Curtis (Republican-Missouri; US House 1963-

The HIPAA of 1996 is a multifaceted statute that contains features most Americans value highly including portability provisions to prevent loss of health insurance brought about by job changes, significant health insurance access, and renewability guarantees, as well as, on an experimental basis, medical savings accounts. ${ }^{43}$ Issues of portability and renewability figured prominently in strategies used to secure the bill's passage. ${ }^{43}$ Under Title II of the new law_-below the heading "Preventing Health Care Fraud and Abuse; Administrative Simplification"-a series of other provisions are found. To peruse the HIPAA law and regulations, visit the following website: http:// aspe.hhs.gov/admnsimp/index.htm. ${ }^{73}$

The Administrative Simplification Rules cover four main provisions: 1) uniform electronic transactions standards for health care data; 2) privacy and confidentiality provisions for individually identifiable health information; 3 ) security procedures to protect electronically maintained health information; and 4) unique health identifiers for providers, employers, plans, and individuals.

The Uniform Electronic Transaction Standard becomes effective October 16, 2003. It is believed that the new uniform electronic transaction rules can provide significant administrative savings and reduce hassles. ${ }^{20}$ For the first time, all health plans and other payers will be required to accept the same single form without any additional or local variations. There will also be uniform code sets that cannot be changed. This will likely yield savings for neurosurgeons who will not have to supervise a staff devoted to properly filling out multiple varieties of claim forms and attachments. ${ }^{20}$

The privacy regulation will introduce new duties for physicians in terms of protecting and accounting for disclosures of patient information. When the HIPAA was passed, consumers demanded these protections as the price of allowing increased electronic transmission of confidential records. These rules take effect April 14, 2003. ${ }^{20}$

All physicians are covered by the HIPAA if they use electronic means to transmit any of the following: health claims, remittance or payment advice, claim status inquiries, eligibility inquiries, enrollment and disenrollment, referral certification and authorization, coordination of benefits, or health plan premium payments. ${ }^{20}$

Following are some of the specific provisions of the privacy rule: ${ }^{19} 1$ ) individually identifiable health information may not be used or disclosed unless specifically approved by the patient or explicitly permitted under the HIPAA. 2) The privacy rule creates two levels of consent: patient consent and patient authorization. In general, patient consent is necessary to release information used for treatment-related purposes, payment, and health care operations, whereas patient authorization is required to disclose information for nontreatment purposes. 3) Disclosure of health information for nontreatment purposes must be limited to the "minimum necessary." 4) A written agreement must be established that provides for appropriate safeguarding of health information with "business associates." 5) Each practice must designate a privacy officer, develop privacy policies and procedures, and provide staff training to ensure that health information is protected.

The Security Rule is supposed to become effective in early 2004 along with the Unique Identifier Rule. Unique identifiers will be set up for all providers, employers, plans, and individuals. The individual health identifier is controversial, and the development of the concept has been suspended. Additional federal privacy legislation may be required to enable this aspect of the statute. ${ }^{20}$

\section{A Closer Look at the Health Insurance Portability and Accountability Act}

Congress and the media did not inform the public about other provisions of the HIPAA, including a bevy of criminal sanctions. Most of these provisions appear in Title II of the new law, and the description that follows is largely owing to the work of Charlotte Twight. ${ }^{43}$ One of the purposes of the new law is to limit Medicare fraud. Accordingly, the law establishes a "fraud and abuse control program" to be administered by the Department of HHS and applied to any "federal health program" defined as "any plan or program that provides health benefits, whether directly, through insurance, or otherwise, which is funded directly, in whole or in part by the United States Government" as well as any state health care program. ${ }^{74}$ These provisions were taken from $\$ 5401$ of the Health Maintenance Act of $1993 .{ }^{43}$ That bill, developed during the early years of the Clinton administration, was presented with great fanfare but many people soon became alarmed by its implications. It would have caused a virtual federal takeover of health care delivery in the US, mandating ubiquitous price and service controls administered by regional alliances reporting to a "National Health Board." ${ }^{43}$ The bill died and for all intents and purposes was forgotten.; however, many of the 1993 provisions that potentially threatened innocent physicians were incorporated into the 1996 law, however, dissent - or even attention to these provisions - scarcely arose. With little notice in the press, the House and Senate gave almost unanimous approval to HIPAA in August 1996. ${ }^{43}$

In provisions taken directly from $\$ 5401$ of the Clinton 1993 bill, the 1996 act allows the Secretary of the Department of HHS "to conduct investigations, audits, eval- 
uations and inspections relating to the delivery of and payment for health care in the United States," to "arrange for the sharing of data with representatives of health plans," and to secure "qualified immunity" for those who provide information to the secretary or attorney general. ${ }^{75}$ Like the rejected 1993 bill's \$5402, it establishes a "Health Care Fraud and Abuse Account." In a section labeled "Beneficiary Incentive Programs," the 1996 law authorizes the secretary of HHS to "encourage" informants and to pay them a portion of amounts collected because of their disclosures. $^{76}$

Under the 1996 act, civil penalties apply to medical practice involving federal health care programs, as well as state health care programs. ${ }^{43}$ Under a new provision of the law headed "Claim for Item or Service Based on Incorrect Coding or Medically Unnecessary Services," civil sanctions can be applied to any person who "engages in a pattern or practice of presenting or causing to be presented a claim for an item or service that is based on a code that the person knows or should know will result in a greater payment to the person than the code the person knows or should know is applicable to the item or service actually provided." 77 Thus, the Secretary of the Department of HHS and the courts are now empowered to determine, after the fact, what the doctor should have known about the codes, for which, in many instances, there is no consistent interpretation. Civil sanctions are also applied if a provider makes a claim "for a pattern of medical or other items or services that a person knows or should know are not medically necessary." 78 The HHS Secretary can determine after the fact whether something was medically necessary. The term "should know" is defined in the statute to mean "deliberate ignorance" or "reckless disregard of the truth or falsity of the information."

An interesting point revolves about the civil sanctions. Twight has pointed out that in response to fears stated by providers of alternative medicine, the conferees stated in the conference report that they "do not intend to penalize the exercise of medical judgment of health care treatment choices made in good faith and which are supported by significant evidence or held by a respectable minority of those providers who customarily provide similar methods of treatment." They also stated that the act "is not intended to penalize providers simply because of a professional difference of opinion regarding diagnosis or treatment." 43 Statutory language that is broad and ambiguous enough to trigger such a disclaimer highlights the dangerous scope of authority granted by the new law. ${ }^{43}$

The 1996 act threatens physicians with potential prosecution of loosely drawn new crimes accorded the designation of "federal health care offenses," investigation of which confers broad subpoena power on the US Attorney General. ${ }^{80}$ Unlike the law's civil sanctions, the criminal penalties extend to all private contracts for medical services; they are not limited to medical practice in connection with Medicare and other federal or state health care programs. In provisions derived almost verbatim from the 1993 Health Security Act, the 1996 law establishes as crimes "health care fraud," "theft or embezzlement in connection with health care," "false statements relating to health care matters," and "obstruction of criminal investigations of health care offenses." 43
Taken almost intact from the Health Security Act, the new federal crime of "health care fraud" specifies criminal penalties of up to 10 years in prison in addition to fines for anyone who "knowingly and willfully executes, or attempts to execute, a scheme or artifice (1) to defraud any health care benefit program; or (2) to obtain, by means of false or fraudulent pretenses, representations, or promises, any of the money or property owned by, or under the custody of control of, any health care benefit program..$^{22,81}$ The fraud-related prison sentence is up to 20 years if the violation "results in serious bodily injury" and up to life in prison if anyone dies. Even an attempt to undertake the proscribed behavior could land a physician in jail for 10 years. Because determination of what constitutes "knowing" and "willful" behavior can only come after the fact, innocent behavior potentially falls under the umbrella of this language. Moreover, attempting to obtain payment for a procedure that the physician considered to be medically necessary, that helped the patient, but that later was deemed unnecessary by government officials could be deemed a "false representation." 43

The conference report, although not the statute, contains a disclaimer. The conference report states regarding $\$ 242$ that the act "is not intended to penalize a person who exercises a health care treatment choice or makes a medical or health judgement in good faith simply because there is a difference of opinion regarding the form of the diagnosis." 82 The existence of such a disclaimer again demonstrates that the language of the statute is broad enough to allow federal authorities to initiate prosecution in situations involving controverted medical judgment. ${ }^{43}$

The second new federal crime, "Theft or embezzlement in connection with health care," was taken in its entirety from $\$ 5437$ of the Clinton administration's 1993 bill. Fines and imprisonment of up to 10 years, or up to 1 year if the amount in question is $\$ 100$ or less, await anyone who "knowingly and willfully... without authority converts to the use of any person other than the original owner, or intentionally misapplies any of the moneys, funds, securities, premiums, credits, property, or other assets of a health care benefit program." 80

The third new federal crime, making "false statements relating to health care matters," specifies fines and up to 5 years of prison time for anyone who "knowingly and willfully-(1) falsifies, conceals, or covers up...a material fact; or (2) makes any materially false...statements or representations...in connection with the delivery of or payment for health care benefits, items or services." ${ }^{33}$ Again, the language was copied from the 1993 bill. Because that which is "knowing and willful" ultimately can be determined only in court, every fee-for-service physician becomes vulnerable under these provisions. Mistakes or controverted judgments of medical necessity may portend criminal prosecutions.

Finally, there is the new federal crime of "Obstruction of criminal investigations of health care offenses." In a provision that threatens not only physicians but also the privacy of medical records, the 1996 law specifies fines and up to 5 years in prison for anyone who "willfully prevents, obstructs, misleads, delays or attempts to prevent, obstruct, mislead, or delay the communication of information or records relating to a violation of a Federal 


\section{J. A. Kusske}

health care offense to a criminal investigator." 84 Accordingly, based on this language, a deliberate decision to withhold medical records for whatever reason-due to concerns about a patient's privacy or even uncertainty about the requesting party's authority-could be used to threaten a physician with imprisonment.

Thus, neurosurgeons engaged in fee-for-service practice will live under the ever-present threat of criminal penalties that burden this new law. The property forfeiture provision alone is noteworthy, requiring the court to order anyone convicted of a federal health care offense "to forfeit property, real or personal, that constitutes or is derived, directly or indirectly, from gross proceeds traceable to the commission of the offense. $"{ }^{85}$ A doctor's house and other assets could be at risk. This, too, was copied from the 1993 Clinton proposal. ${ }^{86}$

\section{Preparation for the Future}

The vagrancy and some of the many contradictions of American health care law are highlighted in this review. What can neurosurgeons do in the short term to prepare for these issues? What can be done in the long term to ameliorate the situation?

In the short term, neurosurgical practices must arm themselves with more information about these statutes and their implications, and they must find a way to comply with them. The law does not mandate compliance programs, but they are encouraged by the OIG. The OIG of HHS recently released its "Guidance"-Compliance Program for Individual and Small Group Physician Practices. ${ }^{29}$ Useful appendices covering fraud and abuse issues and antikickback provisions are included along with this. There are several publications that provide outlines and operational steps to establish such programs. Some are available commercially and others can be obtained from various professional societies.

A compliance program is designed to keep an organization in compliance with applicable legal requirements, by deterring and detecting violations of law. For medical practices, these programs focus on compliance with fraud and abuse laws, Medicare and Medicaid billing regulations, licensing and certification and insurance and HMO laws. Although the OIG states in the Guidance that it believes the great majority of physicians are honest, the OIG also states that "all health care providers have a duty to ensure that the claims submitted to federal health care programs are true and accurate" and that "voluntary compliance programs...provide benefits by not only helping to prevent erroneous or fraudulent claims, but also by showing that the physician practice is making good faith efforts to submit claims appropriately." The Guidance is located on the Internet at the following site: http:// www.oig.hhs.gov.

Meaningfully, in the Guidance itself the OIG emphasizes that physicians are not subject to criminal, civil or administrative penalties for "innocent errors or even negligence." Neurosurgeons with the best of intentions, however, might find a compliance program necessary. Compliance cannot be left to chance in the complex area of health care law in which regulations change quickly. By instituting a compliance program, neurosurgeons can ensure that all of their coworkers understand applicable requirements and their responsibility to adhere to them. The existence of an effective compliance program does not guarantee that one will not be prosecuted under the fraud and abuse laws, but it may be a mitigating factor in any enforcement action.

Compliance programs first came into widespread use in the early 1990s in response to the Federal Sentencing Guidelines for federal crimes. ${ }^{11}$ Under the Guidelines organizations that have "an effective program to prevent and detect violations of law" are treated more favorably than those without compliance programs. As a practical mat-ter, when an employee of an organization is found to be violating the law, the presence, or absence, of a compliance program can play a significant role in the government's decision to prosecute the individual, the organization, or both. ${ }^{31}$

In the Guidance and its Appendix, the OIG has identified a number of "risk areas" of vulnerability for physicians. The OIG recommends including several risk areas in a compliance plan (Table 1).

The OIG also recommends that physicians review its work plan to identify vulnerabilities in areas the OIG has targeted during the preceding 6 months and will concentrate on in the future. The OIG has focused on several areas for the year 2002, including improper Medicare feefor-service payments, physicians at teaching hospitals, reassignment of physician benefits, evaluation and management codes, and critical care codes, among others. A copy of the OIG work plan can be obtained from the following website: http://www.oig.hhs.gov.

A Special Advisory Bulletin entitled "Practice of Business Consultants" was issued by the OIG in June 2001. The OIG warned that even though the vast majority is honest, there are consultants mentoring physicians on how to cheat third-party payers through overbilling, false doc-

TABLE 1

The OIG-recommended risk areas to be included in physicians' compliance programs

Risk Area

\begin{tabular}{l}
\hline Risk Area \\
\hline coding \& billing \\
reasonable \& necessary services \\
local medical review policy \\
advanced beneficiary notices \\
physician liability for certifications for provision of home health \\
services \& medical equipment \& supplies \\
billing for noncovered services as if covered \\
documentation \\
kickbacks, inducements, \& self-referrals \\
rental of space in physician offices by persons or entities to whom/ \\
which physicians refer \\
professional courtesy \\
physician incentive arrangements \\
physician relationships w/ hospitals \\
physician role in the emergency transfer laws \\
teaching physicians \\
gain-sharing arrangements \& civil monetary penalties for hospital \\
payments to physicians to reduce or limit services to beneficiaries \\
physician billing practices \\
third-party billing services \\
billing practices by nonparticipating physicians \\
professional courtesy \\
unlawful advertising \\
\hline
\end{tabular}


umentation, and other practices. The OIG states that "hiring a consultant does not relieve a provider of responsibility for ensuring the integrity of dealings with the federal health care programs" and a consultant's advice may expose a physician to potential liability. ${ }^{30}$

Whatever one claims will be done in the compliance plan should be done. If not, one is noncompliant. The OIG states in the Guidance that "having a plan and not performing it is worse than having no plan." All staff and all neurosurgeons must be involved. This includes scheduling compliance courses and coding meetings. The neurosurgeon in practice has the ultimate responsibility to comply with all applicable statutes and regulations, and he/she needs to be alert to changes. The adoption and application of the practice compliance plan does not absolve the neurosurgeon(s) from this responsibility.

A voluntary compliance plan may not be for everyone. Each physician needs to make an assessment as to whether to adopt a program by considering the size of the group, the ability of the group to commit and adhere to the plan if established, and confidence in what is currently in place. If, for example, the group has been a target of audits or investigations in the past and/or has a model that supports aggressive coding and billing practices, the practice may be at a higher risk and would therefore benefit more from a formal compliance program.

\section{CONCLUSIONS}

A far-reaching review on the many parameters of health care law needs full discussion from both sides of the medical and legal perspectives. The aim of Havighurst's pap$\mathrm{er}^{16}$ was to substantiate the value of creating a private forum in which health care law issues can be discussed. He proposed the creation within the Institute of Medicine of a permanent, professionally staffed Forum on Legal Issues in Health Care. The forum's focus would be law affecting the financing, delivery, and quality of health services. He wrote that the overriding goal of the forum is to assist the legal system in adapting legal thinking and doctrine to the new health care environment.

For the better care of their patients, neurosurgeons, devoted to the advancement of their profession, must pause to consider this ever-expanding body of law. It might be that the legal conundrum could defeat our efforts to supply quality neurosurgery to our patients. We must be ever vigilant and active to maintain whatever freedoms are left so that we can provide patient services while assuring the public that we support the delivery of health care in an environment free of fraud.

\section{Appendix}

Several references in this paper use legal citations. The styles of legal citation are explained in The Bluebook: A Uniform System of Citation (published and distributed by The Harvard Law Review Association, Cambridge, MA). The Fifteenth Edition, published in 1991, was used as reference. All of the statutes, regulations and court cases cited in this paper are in the federal realm. In citations the US Supreme Court is indicated as US. Therefore, a Supreme Court case, for example, is referenced as 421 US 773 (1975), where the first three-digit number is the reporter volume number, the second three-digit number is the first page of the case in the reporter, and third number is the year of publication. Reporters are bound publications that print only cases. Numbered circuits such as " $2 \mathrm{~d}$ Cir" identify the US courts of appeal. An example of a citation would be 48F 3d 937 (6th Cir 1995), where the initial number and letter combination is the reporter volume number and reporter abbreviation, the second three-digit number is the first page of the case, and the third citation is the deciding court, and the fourth is the year of publication. Citation of an individual provision of the United States Code is illustrated in the following example: 42 U.S.C. $\S$ $1395 \mathrm{y}(\mathrm{e})$ where 42 is the volume number, followed by the code abbreviation and then the specific section and subsections cited. Citation of a particular provision in the Code of Federal Regulations is as follows: 42 C.F.R. $\S 1008.5$, where 42 is the C.F.R. volume number, C.F.R. is the abbreviation of the set of regulations cited followed by the section symbol and specific section cited. Citations of the Federal Register are as follows: 66 Fed Reg 856-965, where 66 is the volume number followed by the abbreviation and the page numbers of interest.

\section{References}

1. AMA v. United States, 130F. 2d 233 (D.C. Cir. 1942)

2. Anderson GF, Hurst J, Hussey PS, et al: Health spending and outcome trends in OECO countries, 1960-1998. Health Aff 19: $150-157,2000$

3. Arnett M, Emord J, Hutton L, et al: How medicare paperwork abuses doctors and harms patients. Heritage Lectures 665: May 11, 2000

4. Bell Memorial Hospital v Mutual Hosp Ins Inc., 784 F. 2d 1325 (7th Cir. 1986)

5. Bitterman RA: A critical analysis of the federal COBRA hospital "antidumping law": ramifications for hospitals, physicians and effects on access to health care. Univ Detroit Mercy Law Review 70:125-190, 1992

6. Bitterman RA: Providing Emergency Care Under Federal Law: EMTALA. Dallas: American College of Emergency Physicians, 2000, pp 1-6

7. Blue Cross and Blue Shield of Wisconsin v. Marshfield Clinic, 65 F. 3d 1406 (7th Cir. 1992)

8. Congressional Record 13903 (October 23, 1985) Statement of Rep. Stark

9. Congressional Record 13903 (October 23, 1985) Statement of Sen. Durenberger

10. Consolidated Omnibus Budget Reconciliation Act of 1985. Pub. 1 No. 99-202. Title XI, Section 9121, 100 Stat 167 (1986). Signed into law by President Reagan April 7, 1986 and effective August 1, 1986

11. Federal Sentencing Guidelines. United States Sentencing Commission. Guidelines Manual. 8A1.2.

12. Fraud and Abuse: Do current laws protect the public interest? Colloquium: American Health Lawyers Assn, Washington DC, January 1999

13. Hanson CI, Meghrigan AG, Penney SL, et al: Antitrust, in Moyle PL, Lee HP (eds): California Physician's Legal Handbook. San Francisco: California Medical Association, 2001, pp 6:1-6:33

14. Hanson CI, Meghrigan AG, Penney SL, et al: Fraud and abuse, in Moyle PL, Lee HP (eds): California Physician's Legal Handbook. San Francisco: California Medical Association, 2001, pp 16:1-16:47

15. Hanson CI, Meghrigan AG, Penney SL, et al: Fraud and abuse: referral issues, in Moyle PL, Lee HP (eds): California Physician's Legal Handbook. San Francisco: California Medical Association, 2001, pp 17:1-17:79

16. Havighurst CC: American health care law-we need to talk! Health Aff 19:84-106, 2000

17. Havighurst CC: Antitrust enforcement in the medical services industry: what does it mean? Milbank Mem Fund Q Health Soc 58:89-124, 1980 


\section{J. A. Kusske}

18. Havighurst CC: Freedom of contract. The unexplored path to health care reform, in Feldman RD (ed): American Health Care. New Brunswick: Transaction Publishers, 2000, pp $145-167$

19. HIPAA. Clinician/Senior Management Education and Training Materials. San Francisco: California Healthcare Foundation, 2001

20. HIPAA Compliance. San Francisco: California Medical Association, 2002, pp 1-39

21. Hooper J: What every physician should know about Medicare OIG investigations, in Moyle PL, Lee HP (eds): California Physician's Legal Handbook. San Francisco: California Medical Association, 2001, pp 16:45-16:50

22. Improper Fiscal Year 2000 Medicare Fee-for-Service Payments. Report A-17-00-02000. Washington, DC: Department of Health and Human Services, March 6, 2001

23. Kopit WG, Bouton AB: Antitrust implications of provider exclusion, in Kongstvedt PR (ed): The Managed Health Care Handbook, ed 3. Gaithersburg: Aspen Press, 1996, pp 906-929

24. Krave JP: Fraud and Abuse Basics. A Practical Primer. Los Angeles: Akin, Gump, Strauss, Hauer and Feld, 2001

25. Kusske JA: Neurotrauma care-problems and solutions, in Narayan RK, Wilberger JE Jr, Povlishock JT (eds): Neurotrauma. New York: McGraw-Hill, 1996, pp 995-1005

26. Kusske JA, Orrico K: EMTALA. How Can Neurosurgeons Comply? AANS Bull 10:7-12, 2001

27. Medicare: Lessons Learned from HCFA's Implementation of Changes to Benefits. Washington DC: General Accounting Office, HEHS-00-31, January 2000

28. Omnibus Budget Reconciliation Act of 1989 (OBRA). Pub I: No 101-239, Section 6211(h)(2). 103 Stat 2106, 42 U.S.C. $1395 \mathrm{dd}$

29. OIG Compliance Program for Individual and Small Group Physician Practices. 65 Fed Reg 59434-59452

30. Practice of Business Consultants. Washington DC: Office of the Inspector General, Department of Health and Human Services, 2001

31. Questions and Answers About Compliance Programs. Law Watch. San Francisco: Foley, Lardner, Wassburg and Aronson, 97-17, October 6, 1997

32. Robinson JC: The Corporate Practice of Medicine: Competition and Innovation in Health Care. Berkeley: University of California Press, 1999, pp 28-29

33. Robinson JC: The Corporate Practice of Medicine: Competition and Innovation in Health Care. Berkeley: University of California Press, 1999, pp 231-233

34. Saue JM, Doege GH: ERISA and managed care, in Kongstvedt PR (ed): The Managed Health Care Handbook, ed. 3. Gaithersburg: Aspen Press, 1996, pp 944-966

35. Sheils J, Hogan P: Cost of tax-exempt health benefits in 1998. Health Aff 18:176-181, 1999

36. Slade SR: The false claims act and health care fraud: how far does the act reach? [www.fraudbuster.com/page10.html] (Accessed 11 March 2002)

37. Sparrow MK: License to Steal: Why Fraud Plagues America's Health Care System. Boulder: Westview Press, 1996, pp 212-215

38. Stanton TH: Fraud-and-abuse enforcement in Medicare: finding the middle ground. Health Aff 20:28-42, 2001

39. Stark: Physician self referral, in Kyles T (ed): Fraud and Abuse Answer Book. Rockville: Medicare Compliance Alert, 2001, pp 20402-20466
40. Statements of Antitrust Enforcement Policy in Healthcare. Washington DC: US Department of Justice and the Federal Trade Commission, August 1996, pp 1-141

41. Thornton DM: Sentinel effects shows fraud control effort works. J Health Law (Fall):493-502, 1999

42. The Ethics in Patient Referral Act of 1989. Enacted December 19, 1989. (Stark I)

43. Twight C: Medicare's progeny: the 1996 health care legislation, in Feldman RD (ed): American Healthcare. New Brunswick: Transaction Publishers, 2000, pp 87-118

44. Vogel RL: Deciding whether to file a Qui Tam suit. [www. fraudbuster.com/page4.html] (Accessed 11 March 2002)

45. United States v. Alston, 974F. 2d 1206 (9th Cir 1992)

46. 421 U.S. 773 (1975)

47. 29 U.S.C. $\$ 1001$ et seq

48. 42 C.F.R. $\$ 1001-1091$

49. 42 U.S.C. $\$ 1395 y(\mathrm{e})$

50. 42 U.S.C. $\$ 1320 a-7 b(b)$

51. 42 U.S.C. $\$ 1320 a-7(b)(1)$

52. 42 U.S.C. $\$ 1320 a-7 a(a)(7)$

53. False Claims Act 31 U.S.C. 3729

54. 42 U.S.C. $\$ 1320 a-7 a(a)(5)$

55. 42 U.S.C. $\$ 1395 \mathrm{nn}$

56. 66 Fed Reg $856-965$

57. 42 C.F.R. $\$ 411.351$

58. 42 U.S.C. $\$ 1320 \mathrm{a}-7 \mathrm{~d}$

59. 42 C.F.R. $\$ 1008.5$

60. 42 C.F.R. $\$ 1008.15$

61. 29 U.S.C. $\$ \S 1002(2), 1002(3), 1003$

62. 29 U.S.C. $\$ 1102$

63. 29 U.S.C. $\$ 1022$

64. 29 U.S.C. $\$ \S 1161-1168$

65. FMC v. Holliday. 498 U.S. 52 (1990)

66. $\S 514(a)$ of 29 U.S.C. $\$ 1144 a$

67. $\S 514(\mathrm{~b})(2)(\mathrm{A})$ of 29 U.S.C. $\$ 1144(\mathrm{~b})(2)(\mathrm{a})$

68. $\$ 514(\mathrm{~b})(2)(B)$ of 29 U.S.C. $\$ 1144(\mathrm{~b})(2)(\mathrm{B})$

69. 48 F. 3d 937 (6th Cir 1995)

70. 965F. 2d 132 (5th Cir 1992)

71. 59F. 3d 937 (6th Cir 1995)

72. 57F. 3d 350 (3rd Cir 1995)

73. 42 U.S.C. $\S \S 1171-1179 ; 45$ C.F.R., parts 142, 160, 162

74. 42 U.S.C. $\$ 204(f)$

75. 42 U.S.C. $\$ 201$

76. 42 U.S.C. $\$ 203(b)$

77. 42 U.S.C. $\$ 231$ (c)

78. 42 U.S.C. $\$ 231(\mathrm{e})$

79. 42 U.S.C. $\$ 231(\mathrm{~d})$

80. 42 U.S.C. $\$ 243$

81. 42 U.S.C. $\$ 242(a)$

82. 1996b. U.S. House, 258

83. 42 U.S.C. $\$ 244$

84. 42 U.S.C. $\$ 245$

85. 42 U.S.C. $\$ 249$

86. $\S 5432$ of the Health Maintenance Act of 1993.

Manuscript received February 18, 2002.

Accepted in final form March 29, 2002.

Address reprint requests to: John A. Kusske, M.D., Department of Neurological Surgery, University of California Irvine Medical Center, Building 3, Room 313, 101 The City Drive, South, Orange, California 92868-3298. email: jkusske@uci.edu. 